самоствердження через самоактуалізацію; професійну самореалізацію; самовдосконалення як усвідомлений процес професійної саморегуляції.

\title{
Література
}

1. Климов Е. А. Педагогический труд : психологические составляющие / А. Климов. - М. : Изд. центр «Академия», 2004. - 240 с. 2. Морозов А.В. Креативная педагогика и психология: [учебное пособие]/ Александр Владимирович Морозов, Дмитрий Владимирович Чернилевский. - [2-е изд., испр. и доп.] - М. : Академический Проект, 2004. -- 560 с.

УДК [378+62]:372.874.1

Людмила Цвіркун

\section{РОЗВИТОК ПРОЕКТНО-КОНСТРУКТОРСЬКОЇ КОМПЕТЕНТНОСТІ СТУДЕНТІВ У ПРОЦЕСІ ГРАФІЧНОЇ ПІДГОТОВКИ}

Цвіркун Л. О. Розвиток проектно-конструкторської компетентності студентів у процесі графічної підготовки.

У статті розглянуто наукові поняття «графічна грамотність», «графічна компетентність», «графічна професійна компетентність», «проектно-конструкторська компетентність», уточнено сутність використовуваних понять у процесі графічної підготовки студентів, конкретизовано терміни та сконцентровано увагу на важливості розвитку проектно-конструкторської компетентності студентів у процесі вивчення графічних дисциплін.

Ключові слова: графічна грамотність, графічна компетентність, графічна професійна компетентність, проектно-конструкторська компетентність.

Цвиркун Л. А. Развитие проектно-конструкторской компетентности студентов в процессе графической подготовки.

В статье рассмотрены научные понятия «графическая грамотность», «графическая компетентность», «графическая профессиональная компетентность», «проектноконструкторская компетентность», уточнена суть используемых понятий в процессе графической подготовки студентов, конкретизированы термины и сконцентрировано внимание на важности развития проектно-конструкторской компетентности студентов в процессе изучения графических дисциплин.

Ключевые слова: графическая грамотность, графическая компетентность, графическая профессиональная компетентность, проектно-конструкторская компетентность.

Tsvirkun L. O. The development of design competence of students in the graphic preparation.

The article deals with the scientific concept of «graphic literacy», «graphic competence», «graphics professional competence», «design and engineering expertise», clarifies the nature of the concepts in the image of students, specifies the terms and focuses on the importance of the development of design competence of students in the study of graphic disciplines.

Key words: graphic literacy, graphical competence, graphics professional competence, design and engineering expertise.

Графічна підготовка студентів посідає важливе місце у процесі вивчення графічних дисциплін, оскільки є невід'ємним складником вищої технічної освіти 
майбутнього інженера. Вона розвиває просторову уяву, технічне мислення, здатність до аналізу графічних моделей та форм.

Фундаментом графічної підготовки студентів $\epsilon$ вивчення дисциплін «Нарисна геометрія та інженерна графіка», «Комп'ютерна графіка», які сприяють формуванню професійно необхідних знань, умінь та навичок у процесі навчання. Важливість графічних дисциплін для студентів у майбутній інженерній діяльності зазначається у працях основоположників нарисної геометрії В. Курдюмова, Г. Монжа, Я. Севастьянова, Н. Макарова, Є. Федорова, Н. Риніна та ін.

Вивчення графічних дисциплін спрямоване на розвиток у студентів графічної грамотності та компетентності, що $\epsilon$ необхідним для будь-якого професійно освіченого інженера, який прагне подальшого збагачення та розвитку свого освітнього потенціалу.

Н. Багдасарян зазначає, що «у процесі вивчення графічних дисциплін виявляються міжпредметні зв'язки, можливість сконцентрувати увагу студентів на графічних елементах, наприклад, у курсі інформатики - використання комп'ютерної графіки, курс теоретичної механіки та сопромату - зображення розрахункових схем тощо» $[1, \mathrm{c.} 15]$.

Знання, які студент отримав у процесі вивчення графічних дисциплін (нарисна геометрія, інженерна та комп'ютерна графіка) дають змогу якісніше розв'язувати інженерні завдання у процесі засвоєння інших курсів: «Теоретична механіка», «Деталі машин», «Теорія машин та механізмів» тощо. Якщо студент не володіє уміннями та навичками складання та оформлення графічної та текстової документації, не знає встановлених нормативних стандартів, то йому буде важко в подальшому вивченні загальнотехнічних та спеціальних дисциплін.

Отже, головною метою вивчення графічних дисциплін $є$ багатогранна графічна підготовка, яка повинна відповідати рівню розвитку сучасних інформаційних технологій та графічних систем.

Mema cmammi- обгрунтувати та визначити етапи розвитку проектноконструкторської компетентності студентів у процесі графічної підготовки.

Постає необхідність визначити послідовні етапи розвитку проектноконструкторської компетентності студентів інженерних спеціальностей у процесі вивчення графічних дисциплін, оскільки графічна грамотність $є$ фундаментом графічної підготовки студентів. Так, Н. Багдасарян графічну грамотність розглядає як широкий кругозір, що характеризується обсягом, широтою і глибиною графічних знань, способів графічної діяльності, що передбачає достатню глибину проникнення і розуміння тих чи тих професійно зорієнтованих питань завдяки інтеграції графічної підготовки та загальнопрофесійних знань [1, с. 7].

Графічна грамотність, набута у процесі вивчення дисциплін «Нарисна геометрія і інженерна графіка», «Комп’ютерна графіка» сприяє формуванню графічної професійної компетентності, необхідної для майбутньої інженерної діяльності, оскільки реалізує численні можливості розв'язання розрахунково-графічних завдань 3 широким застосуванням сучасних інформаційних технологій та графічних систем.

На думку О. Мусієнко, графічна компетентність $є$ не лише метою (інженер повинен уміти читати та виконувати креслення, розв'язувати різні інженерні завдання методами нарисної геометрії, інженерної графіки та комп’ютерного моделювання), а й засобом для оволодіння багатьма знаннями в галузі інших спеціальних i загальнопрофесійних дисциплін [3, с. 45].

Отже, сформована графічна грамотність та компетентність надають змогу розглядати професійну компетентність як результат графічної підготовки студентів. Б. Ломов вважає, що професійна компетентність у галузі інженерної графіки передбачає рівень усвідомленого застосування графічних знань, умінь та навичок, що спирається на 
знання функціональних i конструктивних особливостей технічних об'єктів, досвід графічної професійно орієнтованої діяльності, вільну орієнтацію в середовищі графічних інформаційних технологій [2, с. 120].

Треба зауважити, що в сучасних умовах проектно-конструкторська компетентність може успішно формуватися й розвиватися тільки на основі достатнього рівня геометрографічних знань, отриманих у загальноосвітній школі.

Особливої актуальності набуває розвиток проектно-конструкторської компетентності у ВН3, що здійснюють графічну підготовку студентів інженерних спеціальностей. Студенти повинні отримати таку графічну підготовку, що дозволить збагачувати та розвивати одну з необхідних у майбутній інженерній діяльності базових компетентностей.

На основі аналізу наукової літератури можна констатувати, що «графічна грамотність», «графічна компетентність» та «професійна графічна компетентність»- це послідовні етапи формування і розвитку графічної освіченості майбутнього інженера. Ці етапи студент проходить у процесі графічної підготовки, починаючи із ЗОШ та упродовж всього навчання у ВНЗ.

Розглядаючи розвиток проектно-конструкторської компетентності загалом, необхідно зауважити, що це послідовний і складний процес навчання. Визначимо етапи навчання графічних дисциплін у межах вивчення креслення, нарисної геометрії та інженерної графіки, комп'ютерної графіки. Кожен етап у процесі навчання графічних дисциплін - це розвиток базової компетентності, необхідної для майбутньої успішної інженерної діяльності. Етапи розвитку проектно-конструкторської компетентності схематично наведемо у таблиці 1.

Таблиця 1

\section{Етапи розвитку проектно-конструкторської компетентності у процесі графічної підготовки}

\begin{tabular}{|c|c|c|c|}
\hline \multicolumn{4}{|c|}{$\begin{array}{l}\text { Розвиток проектно-конструкторської компетентності студентів } \\
\text { інженерних спеціальностей у процесі графічної підготовки }\end{array}$} \\
\hline \multirow[b]{2}{*}{$\begin{array}{c}\text { Етапи } \\
\text { навчання }\end{array}$} & \multicolumn{3}{|c|}{ Графічна підготовка студентів інженерних спеціальностей } \\
\hline & $\begin{array}{l}\text { Графічні } \\
\text { дисципліни }\end{array}$ & Графічна база & Етапи розвитку \\
\hline $\begin{array}{c}\text { I-й етап } \\
\text { початковий }\end{array}$ & $\begin{array}{c}\text { Креслення } \\
\text { ЗОШ }\end{array}$ & Геометро-графічна база & $\begin{array}{c}\text { Елементарна } \\
\text { графічна } \\
\text { грамотність }\end{array}$ \\
\hline $\begin{array}{l}\text { II-й етап } \\
\text { базовий }\end{array}$ & $\begin{array}{c}\text { Нарисна } \\
\text { геометрія та } \\
\text { інженерна } \\
\text { графіка }\end{array}$ & \begin{tabular}{l}
\multicolumn{3}{l}{ Графічно-нормативна база } \\
умінь та \\
застосування традиційних \\
методів та та правил \\
побудови зображень
\end{tabular} & \multirow{2}{*}{ 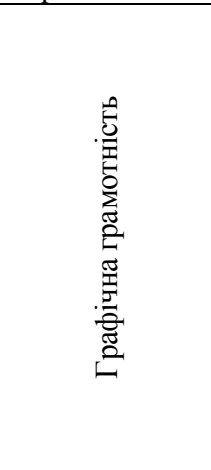 } \\
\hline $\begin{array}{c}\text { III-й етап } \\
\text { закріплювальний }\end{array}$ & $\begin{array}{l}\text { Комп'ютерна } \\
\text { графіка }\end{array}$ & 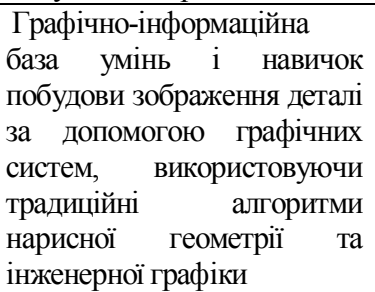 & \\
\hline
\end{tabular}




\begin{tabular}{|c|c|c|c|}
\hline $\begin{array}{r}\text { IV-й етап } \\
\text { формувальний }\end{array}$ & $\begin{array}{c}\text { Спец. } \\
\text { дисципліни }\end{array}$ & $\begin{array}{l}\text { Сформована графічна база } \\
\text { умінь і } \\
\text { необхідних для виконання } \\
\text { проектних } \\
\begin{array}{lr}\text { конструкторських } \\
\text { проектів, } \\
\text { наближених } \\
\text { професійної } \\
\text { діяльності }\end{array} \\
\text { інженерної } \\
\end{array}$ & $\begin{array}{c}\text { Графічна } \\
\text { компетентність }\end{array}$ \\
\hline $\begin{array}{l}\text { V-й етап } \\
\text { творчий }\end{array}$ & $\begin{array}{l}\text { Застосування } \\
\text { графічних ур } \\
\text { інженерної діs }\end{array}$ & $\begin{array}{lll}\text { та збагачення } & \text { отриманих } \\
\text { нь та навичок } & \text { у процесі } \\
\text { bності } & & \\
\end{array}$ & $\begin{array}{c}\text { Професійна } \\
\text { графічна } \\
\text { компетентність }\end{array}$ \\
\hline
\end{tabular}

Якщо студент починає володіти графічними знаннями на початковому етапі навчання й має сформовану елементарну графічну грамотність, то виклад подальшого матеріалу на наступних етапах йому не здається складним, і студент із зацікавленістю продовжує поповнювати та розвивати свої знання на подальших етапах графічної підготовки, отримує високий рівень графічної грамотності й компетентності і як наслідок професійну графічну компетентність в інженерній діяльності. Якщо ж рівень знань не відповідає етапу навчання, то у студента не відбувається необхідний розвиток проектно-конструкторської компетентності, і йому важко адаптуватися до викладу складнішого матеріалу.

Розглянемо етапи навчання студентів інженерних спеціальностей у процесі вивчення графічних дисциплін:

- I-й eman (початковий) - навчання має бути мотиваційно-пізнавальним, майбутній студент ВНЗ у процесі вивчення шкільного курсу креслення повинен мати сформовані геометро-графічні знання, спрямовані на розвиток творчих здібностей та уміння отримувати нові, більші за обсягом знання у процесі подальшого вивчення графічних дисциплін;

- II-ŭ eman (базовий) - на цьому етапі навчання спрямоване на вивчення нормативно визначених графічних знань $з$ поступовим засвоєнням теоретичних понять студентами, відповідно до вимог, необхідних для вивчення дисциплін традиційного графічного циклу на базі нарисної геометрії й інженерної графіки;

- III-й eman (закріплювальний) - студент має певний рівень графічної підготовленості, на цьому етапі він поповнює та вдосконалює отримані знання, застосовуючи сучасні інформаційні технології та графічні системи, використовуючи традиційні алгоритми побудови зображення, що грунтуються на знаннях і правилах нарисної геометрії й інженерної графіки;

- IV-ŭ eman (формувальний) - на цьому етапі студент має фундамент для вивчення подальших спеціальних дисциплін: «Теоретична механіка», «Деталі машин», «Теорія машин та механізмів», що дає змогу виконувати проектні та конструкторські роботи максимально наближені до професійної інженерної діяльності, виконувати графічні розрахунки та будувати геометричні об'єкти у процесі виконання дипломного проекту, що $є$ ключовим у його навчанні у ВНЗ;

- V-ŭ eman (творчий) - студент застосовує та збагачує отримані професійні графічні знання у процесі інженерної діяльності.

Аналіз наукової літератури, робочих планів дає змогу розглянути послідовність навчання графічних дисциплін та виявити зв'язок 3 розвитком проектноконструкторської компетентності студентів інженерних спеціальностей, який має 
безпосереднє відношення до графічної підготовки студентів. Окреслимо етапи розвитку проектно-конструкторської компетентності студентів інженерних спеціальностей:

- елементарна графічна грамотність- уміння правильно читати графічні зображення (креслення, схеми, малюнки, таблиці тощо), будувати їх за допомогою різних креслярських інструментів (циркуля, лінійки, транспортира тощо) акуратно і без помилок;

- графічна грамотність - це усвідомлене застосування нормативно визначених графічних умінь і навичок, необхідних для освіченого інженера, що характеризується обсягом та глибиною, можливістю вільно орієнтуватися у сфері інформаційних технологій та графічних систем;

- графічна компетентність - наявна графічна підготовленість студентів, ефективне застосування отриманих графічних умінь та навичок на основі графічної грамотності, що необхідні для виконання проектних та конструкторських робіт, максимально наближених до професійної інженерної діяльності;

- професійна графічна компетентність - готовність застосовувати у професійній інженерній діяльності отримані графічні уміння та навички у процесі графічної підготовки.

Отже, проектно-конструкторська компетентність - це сформована характеристика готовності студента до майбутньої інженерної діяльності, що виявляється в поетапному накопичуванні нормативно визначених графічних знань, умінь та навичок у процесі графічної підготовки, передбачає вільне володіння інформаційними технологіями та графічними системами, а також здатність застосовувати отримані знання в майбутній професійній діяльності.

Нині майбутній інженер повинен мати сформовану проектно-конструкторську компетентність, знання, які відповідають рівню розвитку сучасних інформаційних технологій та графічних систем, уміти саморозвиватися та вдосконалюватися як творча особистість у процесі професійної діяльності.

\section{Література}

1. Багдасарян Н. Г. Профессиональная графическая культура: структура, динамика, механизмы освоения: автореф. дис. на соискание науч. степени доктора философ. наук: спец. 24.00.01 «Теория и история культуры» / Н. Г. Багдарасян. - М., 1998. - 28 с. 2. Ломов Б. Ф. Вопросы общей, педагогической и инженерной психологии / Б. Ф. Ломов. - М. : Педагогика, 1991. - 296 с. 3. Мусиенко О. А. Развитие профессиональной компетентности студентов строительных специальностей в процессе изучения графических дисциплин: автореф. дис. на соискание науч. степени канд. пед. наук: спец. 13.00.02 «Теория и методика профессионального образования»/ О. А. Мусиенко. - М., 2007. - 22 с.

УДК $378.147: 48$

Елла Часова, Вімалій Івчук

\section{АКТУАЛЬНІ ПИТАННЯ ВИКЛАДАННЯ ПОЧАТКОВОГО КУРСУ ХІМЇ̈ ІНОЗЕМНИМ СТУДЕНТАМ ІНЖЕНЕРНИХ СПЕЦАЛЬНОСТЕЙ НА ПІДГОТОВЧОМУ ВІДДІЛЕНН ВНЗ}

Часова Е. В., Івчук В. В. Актуальні питання викладання початкового курсу хімії іноземним студентам інженерних спеціальностей на підготовчому відділені ВН3.

У статті розглянуто основні проблеми навчання студентів-іноземців в іншомовних вищих навчальних закладах. 3'ясовано деякі чинники, що впливають на успішність навчального процесу. Показана функція адаптованого ефективного навчально- 